\title{
Streptomyces aomiensis sp. nov., isolated from a soil sample using the membrane-filter method
}

\author{
Correspondence \\ Kazuo Shin-ya \\ k-shinya@aist.go.jp \\ Shams Tabrez Khan \\ shamsalig75@gmail.com
}

\author{
Aya Nagai, ${ }^{1}$ Shams Tabrez Khan, ${ }^{1}$ Tomohiko Tamura, ${ }^{2}$ Motoki Takagi ${ }^{1}$ \\ and Kazuo Shin-ya ${ }^{3}$
}

\author{
${ }^{1}$ Biomedicinal Information Research Center (BIRC), Japan Biological Informatics Consortium \\ (JBIC), 2-4-7 Aomi, Koto-ku, Tokyo 135-0064, Japan \\ ${ }^{2}$ NITE Biological Resource Center (NBRC), National Institute of Technology and Evaluation (NITE), \\ 2-5-8 Kazusa-kamatari, Kisarazu, Chiba 292-0818, Japan \\ ${ }^{3}$ Biomedicinal Information Research Center (BIRC), National Institute of Advanced Industrial
Science and Technology (AIST), 2-4-7 Aomi, Koto-ku, Tokyo, 135-0064, Japan
}

\begin{abstract}
A Gram-positive actinobacterium, designated $\mathrm{M} 24 \mathrm{DS}^{\top}$, was isolated from a soil sample collected from Aomi, Tokyo, Japan, using the membrane-filter method. Strain M24DS4 ${ }^{\top}$ exhibited low $16 S$ rRNA gene sequence similarity (96.1\%) with Streptomyces scabrisporus NBRC $100760^{\top}$. Cell hydrolysates contained the LL-isomer of diaminopimelic acid and the predominant

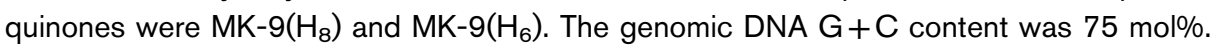
Comparison of the characteristics of strain $\mathrm{M} 24 \mathrm{DS} 4^{\top}$ and related members of the genus Streptomyces with validly published names showed that the strain represents a novel species of the genus, for which the name Streptomyces aomiensis sp. nov. is proposed. The type strain is M24DS4 ${ }^{\top}\left(=\right.$ NBRC $106164^{\top}=$ KACC $\left.14925^{\top}\right)$.
\end{abstract}

Actinomycetes are known to produce pharmaceutically important compounds and have been extensively studied (Bull et al., 2000; McVeigh et al., 1994; Newman \& Hill, 2006). Soil has served as the primary isolation source of these actinomycetes. For the isolation of novel strains from a soil sample, the membrane-filter method described by Hirsch \& Christensen (1983) is used. This method employs a membrane filter $(0.22-0.45 \mu \mathrm{m}$ pore size) to selectively eliminate non-actinomycete bacteria on the basis of their inability to form mycelia. Briefly, the agar plate for isolation is overlaid with a cellulose ester membrane filter and the filter surface is inoculated with a soil suspension. During incubation, the branched mycelia of actinomycetes penetrate the filter through the pores and grow on the underlying medium; bacteria that cannot penetrate the filter fail to grow. The membrane is removed after a few days of incubation and the plate is reincubated to allow the development of actinomycete colonies.

During our studies on the isolation of actinobacteria using the membrane-filter method from a soil sample, strain $\mathrm{M} 24 \mathrm{DS} 4^{\mathrm{T}}$ was isolated from a soil sample collected from Aomi, Tokyo, Japan. A soil sample (1 g) was suspended in

Abbreviation: ISP, International Streptomyces Project.

The GenBank/EMBL/DDBJ accession number for the 16S rRNA gene sequence of strain M24DS4 ${ }^{\top}$ is AB522686.

A supplementary figure and a supplementary table are available with the online version of this paper.
PBS (10 ml) and the solution was serially diluted in sterile water. Aliquots $(100 \mu \mathrm{l})$ of appropriate dilutions were plated on the surface of $0.3 \mu \mathrm{m}$-pore cellulose ester membrane filters (Advantec) on humic acid-vitamin agar (Hayakawa \& Nonomura, 1987) without antibiotics. The membrane filters were removed after 4 days of incubation at $28{ }^{\circ} \mathrm{C}$ and the plates were reincubated at $28{ }^{\circ} \mathrm{C}$ for $2-3$ weeks. Actinomycete colonies appearing on the plates were transferred to International Streptomyces Project (ISP) 2 agar (Shirling \& Gottlieb, 1966) for further purification. For long-term preservation, the isolate was stored at $-80{ }^{\circ} \mathrm{C}$ in $15 \%$ glycerol (v/v).

For analysis of the 16S rRNA gene sequence, genomic DNA was prepared using the Prepman Ultra system (Applied Biosystems). The 16S rRNA gene was amplified using a universal primer set (9f and 1492r; Brosius et al., 1978) and sequenced directly using a BigDye Terminator v3.1 Cycle Sequencing kit and an ABI PRISM 3100 Genetic Analyzer (Applied Biosystems). In BLAST searches (Altschul et al., 1990) comparing the almost-complete 16S rRNA gene sequence (1486 bp) of strain $\mathrm{M} 24 \mathrm{DS} 4^{\mathrm{T}}$ against sequences available in the EzTaxon server (Chun et al., 2007), strain M24DS4 ${ }^{\mathrm{T}}$ showed highest $16 \mathrm{~S}$ rRNA gene sequence similarity $(96.13 \%, 59$ bp difference) with Streptomyces scabrisporus NBRC $100760^{\mathrm{T}}$. 16S rRNA gene sequences related to strain M24DS4 ${ }^{\mathrm{T}}$ were downloaded from DDBJ and a multiple alignment (1430 bp) was created using CLUSTAL X (Thompson et al., 1997). A phylogenetic tree was 


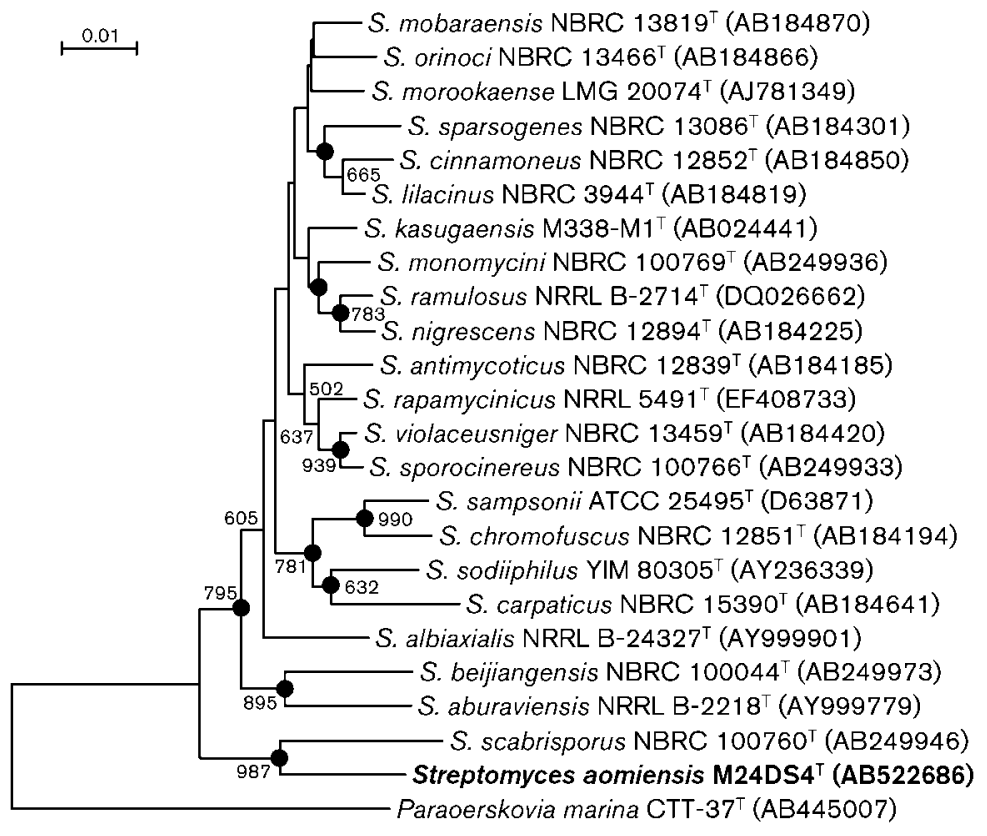

Fig. 1. A neighbour-joining tree based on almost-complete 16S rRNA gene sequences (1430 bp), showing the phylogenetic position of strain M24DS4 ${ }^{\top}$ in the genus Streptomyces. Bootstrap values $(>500)$ based on 1000 resamplings are shown at branch nodes. Filled circles indicate that the corresponding nodes were also recovered in the tree generated with the maximum-parsimony method. Paraoerskovia marina CTT- $37^{\top}$ was used as an outgroup. Bar, $0.01 K_{\text {nuc. }}$.

reconstructed using the neighbour-joining algorithm (Saitou \& Nei, 1987) and the robustness of the tree topology was evaluated by bootstrap analysis (Felsenstein, 1985) using 1000 resamplings of the sequences. Strain M24DS4 ${ }^{\mathrm{T}}$ clustered with S. scabrisporus NBRC $100760^{\mathrm{T}}$ (Fig. 1) as a monophyletic clade supported by a high bootstrap value of $98 \%$. This cluster was also obtained with maximum-parsimony analysis (Swofford, 2000).

Cultural and physiological characteristics of strain M24DS4 ${ }^{\mathrm{T}}$ and S. scabrisporus NBRC $100760^{\mathrm{T}}$ were determined as described by Shirling \& Gottlieb (1966). Growth at 4, 10, 15, $20,28,35$ and $40{ }^{\circ} \mathrm{C}$ was assessed on ISP 2 agar for 6 days. Growth at pH 5 and 6 (adjusted with $\mathrm{HCl}$ ) and $\mathrm{pH} 8,9$ and 10 (adjusted with $\mathrm{NaOH}$ ) was examined on ISP 2 agar at $28{ }^{\circ} \mathrm{C}$ for 9 days. The growth characteristics on ISP 1 and ISP 3-9 were also determined (Shirling \& Gottlieb, 1966). The API ZYM and API Coryne systems (bioMérieux) were used, according to the manufacturer's instructions, for biochemical characterization. Strain M24DS4 ${ }^{\mathrm{T}}$ could be differentiated phenotypically from S. scabrisporus NBRC $100760^{\mathrm{T}}$ by a number of characteristics (Table 1 ), namely spore morphology, aerial mycelium on ISP 2, colony base colour, temperature range for growth, utilization of carbon sources, activities of alkaline phosphatase, $\alpha$-chymotrypsin and urease, and hydrolysis of gelatin.

For strain M24DS4 ${ }^{\mathrm{T}}$, the hyphal arrangement, spore chain morphology and spore surface ornamentation were observed by light microscopy (CX41LF; Olympus) and scanning electron microscopy (JSM-6060; JEOL) after growth on ISP 2 agar at $28{ }^{\circ} \mathrm{C}$ for $15-20$ days. A micrograph showing the spore chain morphology of strain $\mathrm{M} 24 \mathrm{DS} 4^{\mathrm{T}}$ is given in Supplementary Fig. S1 (available in IJSEM Online). Genomic DNA was extracted from cells grown to late exponential growth phase using the protocol of Minamisawa (1990) and the G+C content of the genomic DNA was determined using the method described by Mesbah et al. (1989). Menaquinones, cellular fatty acids and the diaminopimelic acid isomer in whole-cell hydrolysates were determined as described by Tamura et al. (1994). The culture used to determine the fatty acid content was prepared on ISP 2 agar at $28{ }^{\circ} \mathrm{C}$ for 10 days. The fatty acid content of strain M24DS4 ${ }^{\mathrm{T}}$ is given in Supplementary Table S1. Other characteristics are given in the species description.

On the basis of significant differences shown in the $16 \mathrm{~S}$ rRNA gene sequence analysis and the phenotypic differences between strain M24DS4 ${ }^{\mathrm{T}}$ and its closest phylogenetic neighbour (Stackebrandt \& Ebers, 2006), we propose that strain M24DS4 ${ }^{\mathrm{T}}$ should be classified in a novel species of the genus Streptomyces, for which the name Streptomyces aomiensis sp. nov. is proposed.

\section{Description of Streptomyces aomiensis sp. nov.}

Streptomyces aomiensis (ao.mi.en'sis. N.L. masc. adj. aomiensis pertaining to Aomi, the place from where the strain was isolated).

Aerobic and Gram-positive actinomycete. Spore chains are rectiflexibiles and the spore surface is smooth. Spores and aerial mycelium are grey. The diaminopimelic acid isomer in the cell hydrolysate is the LL-type. Growth occurs at $15-37{ }^{\circ} \mathrm{C}$ (optimum $25-28{ }^{\circ} \mathrm{C}$ ). Optimum $\mathrm{pH}$ is $\mathrm{pH}$ 6.0-8.0 (weak growth at $\mathrm{pH} 9.0$ and 10.0). Growth is good on yeast extractmalt extract agar (ISP 2) and peptone-yeast extract iron agar (ISP 6), but is average-to-poor on tryptone yeast extract agar (ISP 1), oatmeal agar (ISP 3), inorganic salts-starch agar (ISP 4), glycerol-asparagine agar (ISP 5) and tyrosine agar (ISP 7). Melanin pigments are not produced on ISP 6 or ISP 7. With 
Table 1. Characteristics that differentiate strain $M 24 D S 4^{\top}$ from its closest recognized phylogenetic neighbour

All data were taken from this study, unless otherwise indicated. +, Positive; w, weakly positive; -, negative.

\begin{tabular}{|c|c|c|}
\hline Characteristic & S. aomiensis sp. nov. M24DS4 $4^{\mathrm{T}}$ & S. scabrisporus NBRC $100760^{\mathrm{T}}$ \\
\hline Spore morphology (SEM) & Rectiflexibiles, smooth & Spiral, rugose ${ }^{\star}$ \\
\hline \multicolumn{3}{|l|}{ Characteristics on ISP 2} \\
\hline Aerial mycelium & Grey & - \\
\hline Colony base colour & Raised, cream-yellow & Wrinkled, light ivory \\
\hline $\begin{array}{l}\text { Temperature range for growth } \\
\left({ }^{\circ} \mathrm{C}\right)\end{array}$ & $15-37$ & $10-37$ \\
\hline \multicolumn{3}{|l|}{ Utilization of: } \\
\hline L-Arabinose & $\mathrm{W}$ & - \\
\hline Inositol & - & + \\
\hline \multicolumn{3}{|l|}{ API ZYM } \\
\hline Alkaline phosphatase & - & + \\
\hline$\alpha$-Chymotrypsin & - & + \\
\hline Valine arylamidase & $\mathrm{w}$ & + \\
\hline Cystine arylamidase & $\mathrm{w}$ & + \\
\hline \multicolumn{3}{|l|}{ API Coryne } \\
\hline Pyrrolidonyl arylamidase & $\mathrm{W}$ & - \\
\hline Urease & - & + \\
\hline Gelatin hydrolysis & - & + \\
\hline
\end{tabular}

${ }^{\star}$ Data taken from Ping et al. (2004).

API ZYM and API Coryne, positive for acid phosphatase, catalase, $\beta$-glucosidase, leucine arylamidase, $N$-acetyl- $\beta$ glucosaminidase, naphthol-AS-BI-phosphohydrolase, pyrazinamidase and nitrate reduction and weakly positive for cystine arylamidase, pyrrolidonyl arylamidase and valine arylamidase, but negative for alkaline phosphatase, esterase, esterase lipase, $\alpha$-chymotrypsin, $\alpha$-fucosidase, $\alpha$ - and $\beta$ galactosidase, $\beta$-glucuronidase, $\alpha$-glucosidase, $\alpha$-mannosidase, lipase, trypsin, urease and gelatin hydrolysis. As sole carbon sources, L-rhamnose, D-glucose, lactose and D-xylose are utilized and L-arabinose, D-fructose, sorbitol and sucrose are weakly utilized, but myo-inositol, D-mannitol and raffinose are not utilized. The predominant fatty acids are iso- $\mathrm{C}_{16: 0}$, anteiso- $\mathrm{C}_{15: 0}$, iso- $\mathrm{C}_{15: 0}$ and $\mathrm{C}_{16: 0}$. The major respiratory quinones are $\mathrm{MK}-9\left(\mathrm{H}_{8}\right)$ and $\mathrm{MK}-9\left(\mathrm{H}_{6}\right)$; a small amount of MK-9 $\left(\mathrm{H}_{4}\right)$ is also present. The DNA $\mathrm{G}+\mathrm{C}$ content of the type strain is $75 \mathrm{~mol} \%$.

The type strain, M24DS4 ${ }^{\mathrm{T}}$ (=NBRC $106164^{\mathrm{T}}=\mathrm{KACC}$ $\left.14925^{\mathrm{T}}\right)$, was isolated from a soil sample using the membrane-filter method.

\section{Acknowledgements}

This work was supported by a grant from the New Energy and Industrial Technology Department Organization (NEDO) of Japan.

\section{References}

Altschul, S. F., Gish, W., Miller, W., Myers, E. W. \& Lipman, D. J. (1990). Basic local alignment search tool. J Mol Biol 215, 403-410.
Brosius, J., Palmer, M. L., Kennedy, P. J. \& Noller, H. F. (1978). Complete nucleotide sequence of a $16 \mathrm{~S}$ ribosomal RNA gene from Escherichia coli. Proc Natl Acad Sci U S A 75, 4801-4805.

Bull, A. T., Ward, A. C. \& Goodfellow, M. (2000). Search and discovery strategies for biotechnology: the paradigm shift. Microbiol Mol Biol Rev 64, 573-606.

Chun, J., Lee, J.-H., Jung, Y., Kim, M., Kim, S., Kim, B. K. \& Lim, Y.-W. (2007). EzTaxon: a web-based tool for the identification of prokaryotes based on $16 \mathrm{~S}$ ribosomal RNA gene sequences. Int J Syst Evol Microbiol 57, 2259-2261.

Felsenstein, J. (1985). Confidence limits on phylogenies: an approach using the bootstrap. Evolution 39, 783-791.

Hayakawa, M. \& Nonomura, H. (1987). Humic acid-vitamin agar, a new medium for the selective isolation of soil actinomycetes. J Ferment Technol 65, 501-509.

Hirsch, C. F. \& Christensen, D. L. (1983). Novel method for selective isolation of actinomycetes. Appl Environ Microbiol 46, 925929.

McVeigh, H. P., Divers, M., Warwick, S., Munro, J. \& Embley, T. M. (1994). Exploration of actinomycete diversity using ribosomal RNA sequences. Biotechnologia 7-8, 253-260.

Mesbah, M., Premachandran, U. \& Whitman, W. B. (1989). Precise measurement of the $\mathrm{G}+\mathrm{C}$ content of deoxyribonucleic acid by highperformance liquid chromatography. Int J Syst Bacteriol 39, 159-167.

Minamisawa, K. (1990). Division of rhizobitoxine-producing and hydrogen-uptake positive strains of Bradyrhizobium japonicum by nifDKE sequence divergence. Plant Cell Physiol 31, 81-89.

Newman, D. J. \& Hill, R. T. (2006). New drugs from marine microbes: the tide is turning. J Ind Microbiol Biotechnol 33, 539-544.

Ping, X., Takahashi, Y., Seino, A., Iwai, Y. \& Ōmura, S. (2004). Streptomyces scabrisporus sp. nov. Int J Syst Evol Microbiol 54, 577581. 
Saitou, N. \& Nei, M. (1987). The neighbor-joining method: a new method for reconstructing phylogenetic trees. Mol Biol Evol 4, 406-425.

Shirling, E. B. \& Gottlieb, D. (1966). Methods for characterization of Streptomyces species. Int J Syst Bacteriol 16, 313-340.

Stackebrandt, E. \& Ebers, J. (2006). Taxonomic parameters revisited: tarnished gold standards. Microbiol Today 33, 152-155.

Swofford, D. L. (2000). PAUP*: phylogenetic analysis using parsimony (and other methods), version 4. Sunderland, MA: Sinaur Associates.
Tamura, T., Nakagaito, Y., Nishii, T., Hasegawa, T., Stackebrandt, E. \& Yokota, A. (1994). A new genus of the order Actinomycetales, Couchioplanes gen. nov., with descriptions of Couchioplanes caeruleus (Horan and Brodsky 1986) comb. nov. and Couchioplanes caeruleus subsp. azureus subsp. nov. Int J Syst Bacteriol 44, 193-203.

Thompson, J. D., Gibson, T. J., Plewniak, F., Jeanmougin, F. \& Higgins, D. G. (1997). The CLUSTAL_X windows interface: flexible strategies for multiple sequence alignment aided by quality analysis tools. Nucleic Acids Res 25, 4876-4882. 